\title{
Hydroxyproline and proline inhibit $\alpha$-amylase from isolated barley aleurone layers
}

\author{
CRAIG C. FREUDENRICH, WILLIAM V. DASHEK \\ Department of Biology, West Vinginia University, Morgantown, \\ West Virginia 26506, U.S.A. \\ (Received: February 11, 1983. Revision accepted: April 11, 1983)
}

\begin{abstract}
Previously, we reported that $1 \mathrm{mM}$ hydroxyproline appeared to inhibit the gibberellic acid-induced release of $\alpha$-amylase from isolated Hordeum vulgare L. cv. Himalaya aleurone layers into an incubation medium. Here, we report our attempts to determine the mechanism(s) for this inhibition and whether this inhibition can be caused by other proline analogues. Both $1 \mathrm{mM}$ hydroxyproline and proline inhibited extracellular $\alpha$-amylase activity without affecting its intracellular activity. This suggested that neither hydroxyproline nor proline impaired the release of $\alpha$-amylase. Lineweaver-Burk plots revealed that both hydroxyproline and proline uncompetitively inhibited $\alpha$-amylase. Thus, the inhibition is probably an assay artifact resulting from the formation of an enzyme-substrate-hydroxyproline or -proline complex. Because azetidine-2-carboxylic acid, glutamic acid and pipecolic acid did not inhibit extracellular $\alpha$-amylase activity, the uncompetitive inhibition of $\alpha$-amylase must be unique to imino acids as well as their precursors and derivatives which possess a five membered ring.
\end{abstract}

Key words: Hordeum vulgare, hydroxyproline, proline, a-amylase, aleurone layers.

\section{INTRODUCTION}

Clel a n d (1967) hypothesized that hydroxyproline (Hyp) could be a specific inhibitor of the synthesis of Hyp-containing glycoproteins, one of which is structural ("extensin") and has been implicated in cell extension (L a m port 1977). Hydroxyproline is an inhibitor of envertase ( $\mathrm{V}$ a u g han and Cusens 1973), an enzymatic protein which is not rich in Hyp. This raises the possibility that Hyp is a general inhibitor of protein synthesis although $\mathrm{Clel}$ a nd (1967) suggests that it is not. 
Isolated Hordeum vulgare L. cv. Himalaya aleurone layers synthesize a variety of hydrolytic enzymes such as $\alpha$-amylase, $\beta$-1, 3-glucanase, protease, ribonuclease and acid phosphatase in response to exogenous $\mathrm{GA}_{3}$ (V a rner and $\mathrm{Ho}$ 1976). Although many compounds, e.g. abscisic acid (ABA) and ethylene, have been employed to determine the mechanism by which $\mathrm{GA}_{3}$ promotes this synthesis ( $\mathrm{V}$ a rner and $\mathrm{Ho}$ 1976), there do not appear to be any reports on the utilization of amino acid analogues to elucidate the mechanism.

In a preliminary study, we reported that $1 \mathrm{mM}$ Hyp inhibited the activity of extracelular $\alpha$-amylase release from isolated $H$. vulgare $\mathrm{L}$. cv. Himalaya aleurone layers which had been incubated $24 \mathrm{~h}$ with $\mathrm{GA}_{3}$ (Freudenrich and Dashek 1980).

This paper reports our attempts to determine whether Hyp inhibits the synthesis and/or release of $\alpha$-amylase (not Hyp rich), the mechanism(s) by which it might do so and whether other proline (Pro) analogues (D a shek and Erickson 1981) as well as Pro itself affect extracellular and/or intracellular $\alpha$-amylase activity.

\section{MATERIALS AND METHODS}

Preparation and incubation of aleurone layers, tissue homogenization and enzyme assays. Hordeum vulgare L. cv. Himalaya aleurone layers were prepared according to $\mathrm{Chrispeels}$ and Varner (1967) and incubated (10 layers/tube) in $2 \mathrm{~cm}^{3}$ of medium $(20 \mathrm{mM}, \mathrm{pH} 5.0$, succinic acid-sodium succinate buffer, $50 \mu \mathrm{g} \cdot \mathrm{cm}^{-3}$ chloramphenicol and $100 \mathrm{mM}$ $\mathrm{CaCl}_{2}$ ) for $24 \mathrm{~h}$ at $23^{\circ} \mathrm{C}$ in darkness on a New Brunswick Gyrotory shaker at $150 \mathrm{rpm}$. Depending upon the experiment, the medium also contained $1 \mu \mathrm{M} \mathrm{GA}_{3}$ with or without either $1 \mathrm{mM}$ Hyp, $1 \mathrm{mM}$ Pro, $1 \mathrm{mM}$ pipecolic (Pip), $1 \mathrm{mM}$ glutamic acid (Glu), 1-1000 $\mu \mathrm{M}$ azetidine-2-carboxylic acid (Azc) or $1 \mu \mathrm{M}$ ABA. The layers were incubated in darkness to prevent isomerization of the $\mathrm{ABA}$ which was employed to check responsiveness of the layers since $\mathrm{ABA}$ is a known inhibitor of $\alpha$-amylase synthesis (V arner and $\mathrm{H}$ o 1976).

Following incubation, the medium was collected and the layers were washed twice with distilled water (first with 1 and then $2.5 \mathrm{~cm}^{3}$ ). The layers were homogenized into $2 \mathrm{~cm}^{3}$ of $0.2 \mathrm{M} \mathrm{NaCl}$ with a mortar and pestle on ice for 5 to $10 \mathrm{~min}$. The mortar and pestle were washed with $2 \mathrm{~cm}^{3}$ of $0.2 \mathrm{M} \mathrm{NaCl}$ which was added to the homogenate. To separate cell wall from cytoplasm, the homogenate was filtered through a single layer of Miracloth (Calbiochem, LaJolla, Ca, USA) in a Büchner funnel. Aliquots of the medium and filtered tissue homogenates were assayed for $\alpha$-amylase according to $\mathrm{Chrispeels}$ and $\mathrm{V}$ arner (1967). One 
unit of $\alpha$-amylase is defined as the amount of enzyme that causes a change in absorbance at $620 \mathrm{~nm}$ of 1 in $1 \mathrm{~min}$.

Enzyme kinetics. To test whether Hyp could interfere with the $a$-amylase assay, enzyme kinetic analyses were performed with substrate solutions either containing or lacking $1 \mathrm{mM}$ Hyp. Aliquots $\left(0.1 \mathrm{~cm}^{3}\right)$ of medium from layers incubated $24 \mathrm{~h}$ with $\mathrm{GA}_{3}$ were assayed for $\alpha$-amylase activity using varying amounts of starch solution $\left(0.25-2.00 \mathrm{~cm}^{3}\right)$. This procedure was repeated with a starch solution that contained $1 \mathrm{mM}$ Hyp. Lineweaver-Burk plots $\alpha$-amylase activity (Fig. 1) were constructed by linear regression and both Vmax and $\mathrm{Km}$ were calculated in the absence and presence of Hyp. A similar study was conducted using Pro (Fig. 2).

Paper chromatography. To determine the purity of the employed compounds, $50 \mu \mathrm{g}$ each of the Hyp, Pro and Glu were spotted onto Whatmann $3 \mathrm{MM}$ chromatography paper. The chromatogram was developed $8 \mathrm{~h}$ in a solvent consisting of ethanol, water and ammonium hydroxide (18:1:1). Separated amino acids were detected by dipping the air-dried chromatogram in a solution consisting of $200 \mathrm{~cm}^{3}$ acetone, 10 $\mathrm{cm}^{3} \mathrm{H}_{2} \mathrm{O}$ and $5 \mathrm{~cm}^{3}$ glacial acetic acid containing $100 \mathrm{mg} \mathrm{CaCl}_{2}$ and $1 \mathrm{~g}$ ninhydrin (Heilmann et al. 1957). Each amino acid migrated as a single spot with $\mathrm{R}_{\mathrm{fs}}$ of 0.100 (Hyp), 0.200 (Pro) and 0.015 (Glu).

Statistical analyses. Because data regarding the statistical distribution of the $\alpha$-amylase response have not been published and because each treatment had a small sample size, we could not assume that the data were normally distributed or that they could be approximated by a normal distribution. Therefore, significant differences between individual treatments $\left(\mathrm{GA}_{3}\right.$ plus Hyp, Pro, Pip, Glu or ABA) and the control $\left(\mathrm{GA}_{3}\right.$ only) were sought by performing multiple comparisons based upon Kruskal-Wallis rank sums (Hollander and Wolfe 1973) with $\alpha=0.05$ and a one-way alternative hypothesis (treatment $<$ control).

\section{RESULTS AND DISCUSSION}

To determine whether Hyp could inhibit the release of $\alpha$-amylase from the periplasmic space, we quantified both extracellular and intracellular $\alpha$-amylase activities and calculated the total amount of enzyme produced by layers which were incubated $24 \mathrm{~h}$ in media containing either $\mathrm{GA}_{3}$ only or $\mathrm{GA}_{3}$ plus Hyp. It is important to note that intracellular activity by our definition includes any portion of the cell enclosed by its wall because our methods cannot distinguish between the periplasmic space and the true intracellular compartment. If Hyp blocked $\alpha$-amylase release, then intracellular $\alpha$-amylase levels should increase due to accumulation of the enzyme either within the cell or the periplasmic space; 
Table 1

Extracellular, intracellular, and total $\alpha$-amylase for aleurone layers incubated with and without hydroxyproline

\begin{tabular}{|c|c|c|c|c|c|c|c|c|c|}
\hline \multirow{3}{*}{ Treatment } & \multicolumn{6}{|c|}{$\alpha$-Amylase units* } & & & \\
\hline & \multicolumn{3}{|c|}{ extracellular } & \multicolumn{3}{|c|}{ intracellular } & \multicolumn{3}{|c|}{ total } \\
\hline & exp. 1 & exp. 2 & exp. 3 & exp. 1 & exp. 2 & exp. 3 & exp. 1 & exp. 2 & exp. 3 \\
\hline$-\mathrm{GA}_{3}$ & $9.03 \pm 3.66$ & $3.49 \pm 1.33$ & $26.95 \pm 9.40$ & $7.45 \pm 2.63$ & $8.40 \pm 0.67$ & $3.23 \pm 1.29$ & 16.48 & 11.89 & 30.18 \\
\hline$+1 \mu \mathrm{M} \mathrm{GA}$ & $29.06 \pm 0.32$ & $12.97 \pm 1.92$ & $86.17 \pm 15.84$ & $22.61 \pm 1.91$ & $16.27 \pm 2.59$ & $8.80 \pm 2.11$ & 51.67 & 29.24 & 94.97 \\
\hline $\mathrm{GA}_{3}+1 \mathrm{mM}$ Нур & $12.10 \pm 3.13$ & $6.01 \pm 1.19$ & $33.32 \pm 12.52$ & $14.61 \pm 1.01$ & $16.40 \pm 2.96$ & $11.45 \pm 1.64$ & 26.71 & 22.41 & 44.77 \\
\hline $\mathrm{GA}_{3}+1 \mu \mathrm{M}$ ABA & $9.18 \pm 4.43$ & $5.18 \pm 0.44$ & $25.08 \pm 11.09$ & $13.73 \pm 2.75$ & $13.00 \pm 0.33$ & $10.43 \pm 3.31$ & 22.91 & 18.18 & 35.51 \\
\hline $\begin{array}{l}\text { Kruskal- } \\
\text {-Wallis } \\
\text { probabilities }\end{array}$ & $\mathrm{p}=0.005$ & $\mathrm{p}<0.001$ & $\mathrm{p}<0.001$ & $\mathrm{p}<0.001$ & $\mathrm{p}<0.001$ & $\mathrm{p}=0.025$ & & & \\
\hline
\end{tabular}

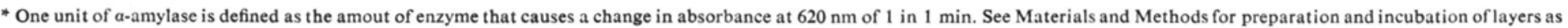
well as assay of $a$-amylase. Data represent the $\bar{x} \pm$ S.D. for each treatment. Experiments 1, 2, etc. in Tables 1-3 are experimental replications. 
extracellular $\alpha$-amylase should decrease; and the total amount of the enzyme should be identical for $\mathrm{GA}_{3}$ and $\mathrm{GA}_{3}$ plus Hyp-treated layers. If Hyp inhibited $\alpha$-amylase by some other mechanism such as inhibiting the synthesis of $\alpha$-amylase, then there should be less $\alpha$-amylase activity within the $\mathrm{GA}_{3}$ plus Hyp-treated layers than within those treated with $\mathrm{GA}_{3}$ only.

The results of these experiments are presented in Table 1. The $\mathrm{GA}_{3}$ increased extracellular $\alpha$-amylase activity 2.3 - to 3.8 -fold and this enhanced activity was partially $(73.4-89.2 \%)$ and completely inhibited by $1 \mathrm{mM}$ Hyp and $1 \mu \mathrm{M}$ ABA, respectively. With respect to intracellular $\alpha$-amylase, neither Hyp nor ABA consistently reduced $\mathrm{GA}_{3}$-enhanced, extracellular $\alpha$-amylase activity. Finally, $\mathrm{GA}_{3}$ enhanced total $\alpha$-amylase activity 2.5 - to 3.2 -fold and this activity was reduced 30.8 to $83.7 \%$ by $1 \mathrm{mM}$ Hyp and 63.6 to $96.2^{\circ} \%$ by $1 \mu \mathrm{M}$ ABA.

Because $\alpha$-amylase did not accumulate within aleurone layers incubated with $\mathrm{GA}_{3}$ plus Hyp and because Hyp inhibited extracellular and total $\alpha$-amylase activities, we conclude that Hyp does not affect $\alpha$-amylase release and, therefore, that Hyp must inhibit $\alpha$-amylase activity by some other mechanism.

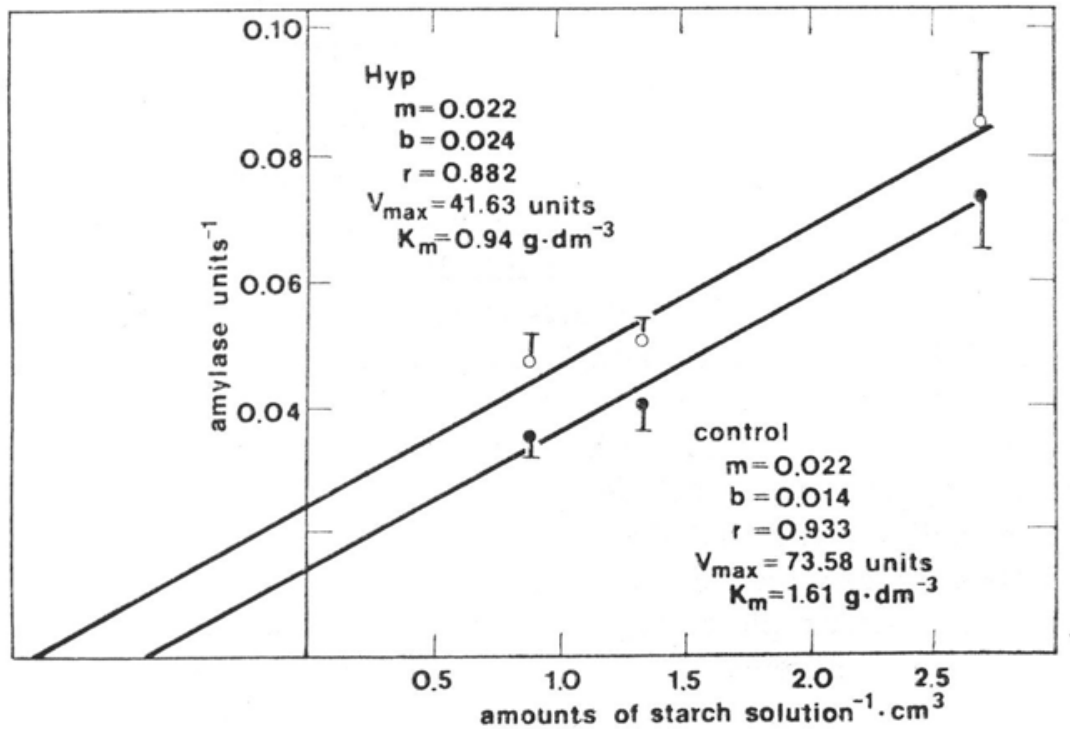

Fig. 1. Lineweaver-Burk plots of $\alpha$-amylase activities utilizing a starch solution with and without Hyp. Aliquots $\left(0.1 \mathrm{~cm}^{3}\right)$ of medium from layers incubated with $\mathrm{GA}_{3}$ as in Materials and Methods were assayed for $\alpha$-amylase activity using varying amounts of starch solution $\left(0.25-2.00 \mathrm{~cm}^{3}\right)$ with a starch solution that contained $1 \mathrm{mM}$ Pro. Data represent the $95 \%$ confidence interval about the mean from two experiments and the lines were constructed by employing linear regression. The slope (m), Y-intercept (b), correlation coefficient (r), maximal velocity (Vmax) and Michaelis constant $(\mathrm{Km})$ are shown for each line 
Hyp uncompetitively inhibits $\alpha$-amylase activity. Since we did not have methods available to adequately measure the synthesis of $\alpha$-amylase, we tested another possibility. Could Hyp interfere with the reaction cytalized by $\alpha$-amylase, i.e. the basis of the assay, thereby producing an artifactual inhibition? To determine if this was indeed true, enzyme kinetic analyses were conducted with and without the inclusion of Hyp within the substrate solution. Lineweaver-Burk plots (Fig. 1) revealed that Hyp is an uncompetitive inhibitor of $\alpha$-amylase activity since the lines representing enzyme activity in the absence and presence of Hyp were parallel (Lehninger 1975). The inhibition of the enzyme's Vmax is about $43.4 \%$, which is within the range of the Hypinduced diminution of total $\alpha$-amylase activity observed in Table 1 . Since an uncompetitive inhibitor acts by forming an enzyme-substrate-inhibitor complex (Lehninger 1975), it is possible that Hyp may complex with $\alpha$-amylase and the starch solution, introduced during the assay procedure, thereby producing the observed inhibition.

Pro inhibits $\alpha$-amylase activity. Since free Hyp is a non-naturally occurring Pro analogue ( $\mathrm{Lamport} \mathrm{1965),} \mathrm{we} \mathrm{determined} \mathrm{whether}$ Pro could inhibit $\alpha$-amylase activity by quantifying the extracellular, intracellular and total $\alpha$-amylase activities for layers incubated $24 \mathrm{~h}$ with and without $\mathrm{GA}_{3}, \mathrm{GA}_{3}$ plus Pro and $\mathrm{GA}_{3}$ plus ABA. As shown in Table 2A, $1 \mu \mathrm{M} \mathrm{GA}_{3}$ increased extracellular $\alpha$-amylase activity 2.9 - to 48.2-fold and this enhanced activity was inhibited either 28.7 to $54.2 \%$ or 60.7 to $89.2 \%$ by $1 \mathrm{mM}$ Pro and $1 \mu \mathrm{M}$ ABA, respectively. In contrast, $\mathrm{GA}_{3}$ promoted intracellular $\alpha$-amylase activity approximately 1.5 -fold (but not consistently) and this activity was usually by $1 \mu \mathrm{M}$ ABA (13.7$-44.5^{\circ} \%$ ), but only occassionally by $1 \mathrm{mM}$ Pro (Table $2 \mathrm{~B}$ ). Total $\alpha$-amylase activity (Table 3) was enhanced 2.2- to 6.7 -fold by $\mathrm{GA}_{3}$ and reduced by both $1 \mathrm{mM}$ Pro (23.3-46.9\%) and $1 \mu \mathrm{M}$ ABA (49.6-78.1\%).

Because the $\mathrm{GA}_{3}$-enhanced extracellular and total $\alpha$-amylase activities were suppressed by Pro, while intracellular $\alpha$-amylase activity was unaffected by Pro, we conclude that Pro, like Hyp, can indeed inhibit $\alpha$-amylase activity and that Pro does not inhibit the release of $\alpha$-amylase from isolated barley aleurone layers.

Lineweaver-Burk plots (Fig. 2) of $\alpha$-amylase activity determined in the presence and absence of Pro suggest that it, like Hyp, is an uncompetitive inhibitor of $\alpha$-amylase activity. The inhibition of the enzyme's Vmax $(47.5 \%)$ is similar to the diminution of both the extracellular (Table 2) and total (Table 4) enzyme activities. Therefore, the observed inhibitions of $\alpha$-amylase activity by Hyp and Pro may be artifacts of the $a$-amylase assay procedure caused by the introduction of starch and subsequent formation of an enzyme-starch-Hyp or -Pro complex.

Other Pro analogues did not inhibit $\alpha$-amylase activity to approximately the same degree. Thus, the hydroxyl group of Hyp is probably 
Table 2A

Extracellular $\alpha$-amylase activity

\begin{tabular}{|c|c|c|c|c|c|c|}
\hline \multirow{2}{*}{ Treatment } & \multicolumn{5}{|c|}{$\alpha$-Amylase units* } & \multirow[b]{2}{*}{ exp. 6} \\
\hline & exp. 1 & exp. 2 & exp. 3 & exp. 4 & exp. 5 & \\
\hline$-\mathrm{GA}_{3}$ & $3.48 \pm 3.44$ & $0.73 \pm 1.14$ & $11.96 \pm 6.62$ & $0.00 \pm 0.00$ & $6.51 \pm 5.36$ & $2.93 \pm 2,27$ \\
\hline$+1 \mu \mathrm{M} \mathrm{GA}_{3}$ & $35.11 \pm 32.81$ & $35.20 \pm 17.75$ & $34.51 \pm 5.64$ & $27.50 \pm 5.28$ & $61.08 \pm 2.74$ & $69.67 \pm 3.90$ \\
\hline $\mathrm{GA}_{3}+1 \mathrm{mM}$ Pro & $16.50 \pm 1.35$ & $20.17 \pm 9.46$ & $24.61 \pm 11.52$ & $11.55 \pm 1.20$ & $27.96 \pm 3.97$ & $\ldots$ \\
\hline $\mathrm{GA}_{3}+1 \mathrm{mM}$ Pip & - - - & $\longrightarrow \cdots$ & $-\cdots-\cdots$ & $52.71 \pm 4.65$ & $61.51 \pm 9.85$ & \\
\hline $\mathrm{GA}_{3}+1 \mathrm{mM}$ Glu & $\cdots \cdots$ & $\longrightarrow$ & $\cdots-\cdots$ & $25.85 \pm 12.58$ & - - - - - - & $73.25 \pm 5.99$ \\
\hline $\mathrm{GA}_{3}+1 \mu \mathrm{M} \quad \mathrm{ABA}$ & $9.26 \pm 1.57$ & $9.17 \pm 3.64$ & $13.54 \pm 3.15$ & $10.82 \pm 0.57$ & $6.60 \pm 1.74$ & 一一一- \\
\hline $\begin{array}{l}\text { Kruskal- } \\
\text {-Wallis } \\
\text { probabilities }\end{array}$ & $\mathrm{p}<0.01$ & $\mathrm{p}<0.001$ & $\mathrm{p}<0.001$ & $\mathrm{p}<0.001$ & $\mathrm{p}<0.001$ & $\mathrm{p}<0.01$ \\
\hline
\end{tabular}

* See Materials and Methods for preparation and incubation of layers as well as assay of $a$-amylase. 
Table 2B

Intracellular $\alpha$-amylase activity

\begin{tabular}{|c|c|c|c|c|c|c|}
\hline \multirow{2}{*}{ Treatment } & \multicolumn{6}{|c|}{$\alpha$-Amylase units* } \\
\hline & exp. 1 & exp. 2 & exp. 3 & exp. 4 & exp. 5 & exp. 6 \\
\hline$-\mathrm{GA}_{3}$ & $8.07 \pm 2.08$ & $7.73 \pm 1.13$ & $7.13 \pm 0.74$ & $8.50 \pm 0.62$ & $8.50 \pm 0.45$ & $8.77 \pm 1.10$ \\
\hline$+1 \mu \mathrm{M} \mathrm{GA}_{3}$ & $11.00 \pm 1.91$ & $6.77 \pm 0.32$ & $6.87 \pm 0.53$ & $12.87 \pm 0.21$ & $11.40 \pm 0.61$ & $8.97 \pm 0.98$ \\
\hline $\mathrm{GA}_{3}+1 \mathrm{mM}$ Pro & $8.60 \pm 0.73$ & $9.87 \pm 0.30$ & $7.13 \pm 0.41$ & $9.90 \pm 2.50$ & $11.50 \pm 0.64$ & ------ \\
\hline $\mathrm{GA}_{3}+1 \mathrm{mM}$ Pip & $-\cdots---$ & ------ & ------ & $10.60 \pm 0.95$ & $12.00 \pm 0.22$ & ----- \\
\hline $\mathrm{GA}_{3}+1 \mathrm{mM}$ Glu & $-\cdots---$ & ------ & ------ & $12.50 \pm 1.46$ & ------ & $7.10 \pm 0.39$ \\
\hline $\mathrm{GA}_{3}+1 \mu \mathrm{M}$ ABA & $6.10 \pm 1.45$ & $8.80 \pm 1.32$ & $5.93 \pm 0.27$ & $9.53 \pm 1.66$ & $19.27 \pm 3.30$ & ------ \\
\hline $\begin{array}{l}\text { Kruskal- } \\
\text {-Wallis } \\
\text { probabilities }\end{array}$ & $\mathrm{p}<0.10$ & $\mathrm{p}=0.016$ & $\mathrm{p}<0.01$ & $\mathrm{p}<0.001$ & $\mathrm{p}<0.05$ & $\mathrm{p}<0.01$ \\
\hline
\end{tabular}

* See Materials and Methods for preparation and incubation of layers as well as assay of $\alpha$-amylase.

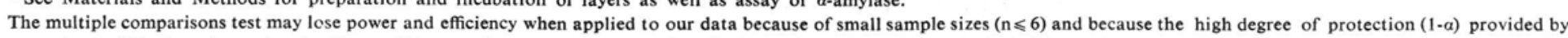

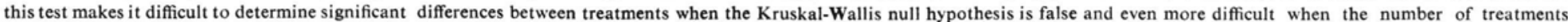

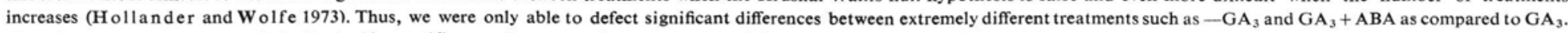

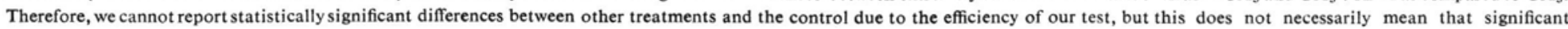

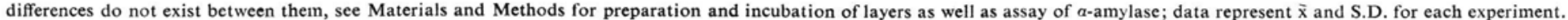


Table 3

Total $\alpha$-amylase activity

\begin{tabular}{|l|c|c|c|c|c|c|}
\hline \multirow{2}{*}{ Treatment } & \multicolumn{7}{|c|}{$\alpha$-Amylase units* } \\
\cline { 2 - 8 } & exp. 1 & exp. 2 & exp. 3 & exp. 4 & exp. 5 & exp. 6 \\
\hline$-\mathrm{GA}_{3}$ & 11.55 & 8.46 & 19.09 & 8.50 & 15.01 & 11.70 \\
$+1 \mu \mathrm{M} \mathrm{GA}_{3}$ & 46.11 & 43.23 & 41.38 & 40.37 & 72.48 & 78.64 \\
$\mathrm{GA}_{3}+1 \mathrm{mM}$ Pro & 25.10 & 30.04 & 31.74 & 21.45 & 39.46 & - \\
$\mathrm{GA}_{3}+1 \mathrm{mM}$ Pip & - & - & - & 63.31 & 73.51 & - \\
$\mathrm{GA}_{3}+1 \mathrm{mM}$ Glu & - & - & - & 38.35 & - & -150.35 \\
$\mathrm{GA}_{3}+1 \mu \mathrm{M}$ ABA & 15.36 & 17.97 & 19.47 & 20.35 & 15.87 & - \\
\hline
\end{tabular}

* See Materials and Methods for preparation and incubation of layers as well as assay of a-amylase and $a$-amylase units. Experiments 1-6 are experimental replications.

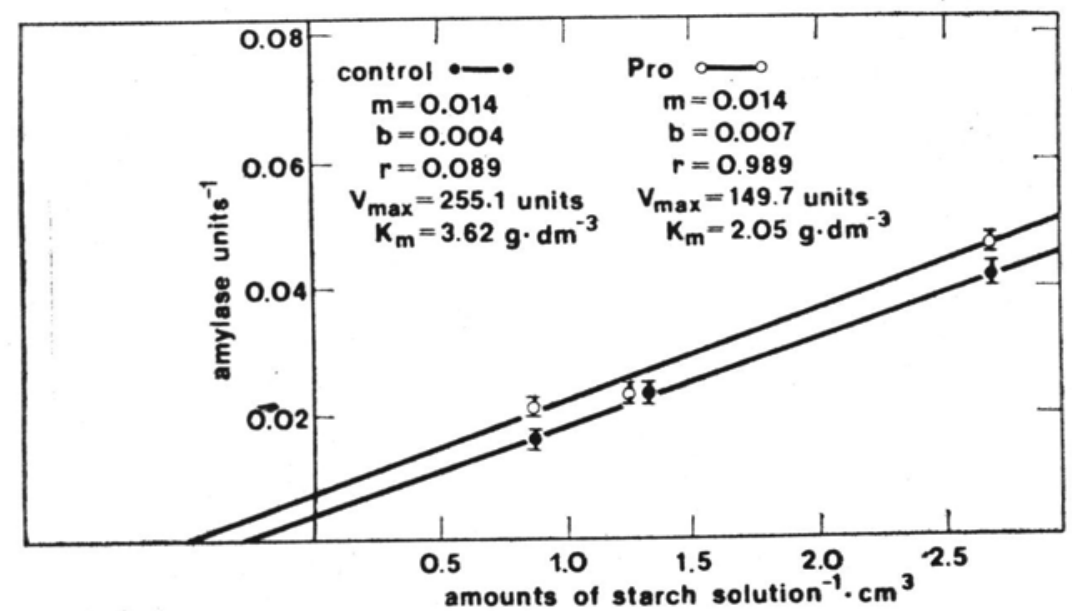

Fig. 2. Lineweaver-Burk plots of $a$-amylase activities utilizing a starch solution with and without Pro. The procedure is the same as that described in Fig. 1, except that $1 \mathrm{mM}$ Pro was substituted in place of Hyp. Data represent the $95 \%$ confidence interval about the mean from two experiments and the lines were constructed using linear regression. The slope (m), Y-intercept (b), correlation coefficient (r), maximal velocity (Vmax) and Michaelis constant $(\mathrm{Km})$ are depicted for each line

not involved in this suppression. Both Hyp and Pro are imino acids with a five-membered ring. Therefore, we tested other Pro analogues such as Pip (six-membered ring) and Azc (four-membered ring) and Glu (a biosynthetic precursor of Pro) to determine wheather they could also impair $a$-amylase activity.

Neither 1-1000 $\mu \mathrm{M}$ Azc (Table 4), $1 \mathrm{mM}$ Pip (Table 2B) nor $1 \mathrm{mM} \mathrm{Glu}$ (Table 2A), inhibited $\mathrm{GA}_{3}$-enhanced extracellular $\alpha$-amylase activity. Likewise, neither Pip nor Glu consistently decreased $\mathrm{GA}_{3}$-enhanced intracellular (Table 2B) and total (Table 3) $a$-amylase activities. Therefore, since none of these Pro analogues tested consistently inhibited $\alpha$-amylase 
activity, we suggest that uncompetitive inhibitions of $\alpha$-amylase activity, which were observed with both Hyp and Pro, must be unique to those imino acids as well as their precursors and derivatives which have a five-membered ring.

Table 4

Effects of Azc on $\alpha$-amylase release from 24-h-incubated layers

\begin{tabular}{|l|c|}
\hline Treatment & Units extracellular $\alpha$-amylase* \\
\hline$-\mathrm{GA}_{3}$ & $1.70 \pm 0.60$ \\
$+1 \mu \mathrm{M} \mathrm{GA}$ & $33.50 \pm 16.60$ \\
$\mathrm{GA}_{3}+1000 \mu \mathrm{M} \mathrm{AZC}$ & $30.80 \pm 3.00$ \\
$\mathrm{GA}_{3}+10 \mu \mathrm{M} \mathrm{AZC}$ & $29.80 \pm 13.30$ \\
$\mathrm{GA}_{3}+1 \mu \mathrm{M} \mathrm{AZC}$ & $26.50 \pm 7.60$ \\
\hline
\end{tabular}

* See Materials and Methods for preparation and incubation of layers as well as assay of $\alpha$-amylase and $\alpha$-amylase units. Data represent $\bar{x}$ and S.D. of three replicate experiments.

Both Hyp and Pro can uncompetitively inhibit $\alpha$-amylase activity by reacting with the $a$-amylase-starch complex. The observed reductions of $a$-amylase in the medium from isolated barley aleurone layers by Hyp and Pro must have been an artifact caused by introducing the starch solution during the assay procedure. This could explain why extracellular $\alpha$-amylase activity is inhibited to the greatest extend because after a $24 \mathrm{~h}$ incubation, most of either the Hyp or Pro is probably within the medium.

Although the inhibitions of $\alpha$-amylase activity for isolated barley aleurone layers by both Hyp and Pro may be artifacts and the concentrations of amino acids used were higher than physiological, we believe that it is interesting that both Hyp and Pro can interfere with an enzymatic reaction in which they are either not involved in or related to. Furthermore, it is noteworthy that this inhibition appears to be unique to those imino acids and their derivatives and precursors which possess a five-membered ring.

\section{Acknowledgments}

We thank Miss Theresa Kolibash for her technical assistance, and Drs. Gretchen $\mathrm{V}$ an Meer and John Krall for their statistical advice. We appreciate the clerical assistance of Joyce Costain.

\section{REFERENCES}

Chrispeels M. J., Varner J. E., 1967. Gibberellic acid-enhanced synthesis and release of $\alpha$-amylase and ribonuclease by isolated barley aleurone layers. Plant Physiol. 42: 398-406. 
Cleland R., 1967. Inhibition of formation of protein-bound hydroxyproline by free hydroxyproline in Avena coleoptiles. Plant Physiol. 42: 1154-1170.

Dashek W. V., Ericks on S. S., 1981. Isolation, assay, biosynthesis, metabolism, uptake and translocation, and function of proline in plant cells and tissues. Bot. Rev. 47: 349-385.

Freudenrich C. C., Dashek W. V., 1980. Do proline analogues inhibit Hordeum vulgare, cv. 'Himalaya' seed germination, seedling growth, and aleurone layer $\alpha$-amylase? Plant Physiol. 65 (Suppl.): 93.

Heilmann J., Barrollier J., Watzke E., 1957. Beitrag zur Aminosaurebestimmung auf Papierchromatogrammen. Z. Physiol. Chem. 302: 1-12.

Hollander M., Wolfe D. A., 1973. Nonparametric Statistical Methods. Wiley, New York. pp. 114-132.

Lamport D. T. A., 1965. The protein component of primary cell walls. In: Advances in Botanical Research. Vol. 2. Preston R. D. (ed.), Academic Press, New York, pp. 151-218.

Lamport D. T. A., 1977. Structure, biosynthesis and significance of cell wall glycoproteins. Rec. Adv. Phytochem. 11: 79-115.

Lehninger A. L., 1975. Biochemistry. Worth Publishers, New York. pp. 198-200.

Varner J. E., Ho D. T., 1976. The role of hormones in the integration of seedling growth. In: The Molecular Biology of Hormone Action. Papaconstantinou J. (ed.), Academic Press, New York. pp. 173-194.

Vaughan D., Cusens E., 1973. Effects of hydroxyproline on the growth of excised root segments of Pisum sativum under aseptic conditions. Planta 112: 243-252.

Hydroksyprolina i prolina inhibuja a-amylaze $z$ warstwy aleuronowej wyizolowanej $z$ jęczmienia

Streszczenie

Uprzednio stwierdziliśmy, że $1 \mathrm{mM}$ hydroksyprolina inhibuje, indukowane przez kwas giberelinowy, uwalnianie $\alpha$-amylazy z izolowanej warstwy aleuronowej Hordeum vulgare L. cv. Himalaya. W tej pracy usiłujemy określić mechanizm(y) tej inhibicji oraz stwierdzić czy inne analogi proliny wykazują taką inhibicję. Zarówno $1 \mathrm{mM}$ hydroksyprolina jak i prolina obie inhibują aktywność $\alpha$-amylazy zewnątrzkomórkowej, natomiast nie wpływają na jej aktywność wewnątrzkomórkową. To sugeruje, że ani hydroksyprolina ani prolina nie osłabiają uwalniania $\alpha$-amylazy. Krzywa Lineweavera-Burka wykazała, że zarówno hydroksyprolina jak i prolina niekompetycyjnie inhibują $\alpha$-amylazę. Tak więc, inhibicja jest najprawdopodobniej artefaktem doświadczalnym, spowodowanym tworzeniem się kompleksów enzym-substrat-hydroksyprolina lub -prolina. Ponieważ kwasy azetydyno-2-karboksylowy, glutaminowy i pipekolowy nie inhibują aktywności $\alpha$-amylazy zewnątrzkomórkowej, niekompetycyjna inhibicja $\alpha$-amylazy musi być jedyną w swoim rodzaju dla iminokwasów jak i ich prekursorów i pochodnych, które mają pierścień pięcio-członowy. 